\title{
ANALISIS EKONOMI AKIBAT COVID DENGAN MATEMATIKA DAN 19 DALAM METODE HAHSLM
}

\author{
R Mochamad A \\ State Islamic University Jakarta \\ reflexivity.centre@gmail.com
}

\begin{abstract}
Received:
06/01/2021

Abstract

Accepted :

$13 / 01 / 2021$

This research was conducted to see the relationship between economics and mathematics and Islam. In this study, it is explained that there is a relationship between the existing phenomena, namely Covid 19 with the mathematics number 19 and Islam and economics. The approach taken in this research is descriptive analysis approach and literature study. While the methodology used is the Hahslm method and comparative analysis. From the test results in this study it was found

Published : that the number 19 is a god of worship, where God creates something on the basis

21/01/2021 of worship. In addition, it is in accordance with the Hahslm formula 472319. Number 19 is related to Covid 19 which has resulted in changes in the level of the global economy. This change in the level of the economy can be explained in mathematics to determine the amount of GDP. This economic level will improve over time and the discovery of a vaccine from the COVID-19 pandemic.
\end{abstract}

Keywords: grade point, biner logistic models, cluster sampling

\begin{abstract}
Abstrak
Model regresi linier logistik dapat digunakan untuk menentukan peluang mahasiswa memperoleh indeks prestasi (IP) di bawah 3,00. Model regresi logistik biner juga bisa digunakan untuk menganalisa faktorfaktor internal dan faktor-faktor eksternal yang diduga mempengaruhi indeks prestasi (IP) mahasiswa. Faktor-faktor intenal berasal dari mahasiswanya sendiri, sedangkan faktor eksternal berasal dari lingkungan keluarga dan masyarakat. Populasi penelitian Populasi penelitian ini adalah mahasiswa perguruan tinggi yang ada di Pangkalpinang propinsi Kepulauan Bangka Belitung. Pengambilan sampel dilakukan dengan cluster sampling berdasarkan pengelompokan tertentu. Metode yang digunakan dalam penelitian ini adalah survei terhadap mahasiswa-mahasiswa di perguruan tinggi yang ada di Pangkalpinang dengan menggunakan kuisioner. Kuisioner berisi variabel Y berupa indeks prestasi dan X berupa variabelvariabel bebas yaitu pendidikan ayah, pendidikan ibu,uang saku setiap bulan, motivasi, sikap mahasiswa, domisili, jenis kelamin dan waktu belajar. Berdasarkan variabel- variabel tersebut, semua faktor internal dan eksternal mempengaruhi indeks prestasi mahasiswa. Persentase faktor internal dan eksternal menunjukkan angka di atas $60 \%$ dan dari analisa juga diperoleh hasil penel.
\end{abstract}

Kata Kunci: Indeks Prestasi, Regresi Logistik Biner, Cluster Sampling

\section{Pendahuluan}

\subsection{Latar Belakang}

Integrasi sains (ilmu pengetahuan) dan agama masih cenderung sebagai wacana.

Namun belum nampak adanya bukti konkret yang menunjukan bahwa sains dan agama itu terintegrasi atau dapat diintegrasikan (Awan, 2009). Dalam matematika juga terdapat istilah nilai numerik atau gematrical. Nilai numeric suatu huruf adalah bilangan yang dipasangkan pada huruf tersebut (Nasution, 2013). Bilangan 19 merupakan bilangan 
prima. Dimana bilangan prima itu sendiri memiliki arti yaitu bilangan asli yang bernilai 1 dan mempunyai 2 faktor pembagi, yaitu 1 dan bilangan itu sendiri (Syah, 2014). Ini membuktikan bahwa sifat Allah yang tidak dapat disamakan dengan makhluk. Selain itu dalam ilmu matematika terdapat hexagon magig normal nontrival yang memiliki Sembilan sel.

Selain dalam matematika, Al-Qur'an juga berbicara tentang bilangan. Dalam AlQur'an disebutkan beberapa bilangan misalnya satu (wahid), tiga (tsalaatsah), tujuh (sab'ah), dan sembilan belas (tits'a 'asyarah) (Irawan, 2005). Patut disadari bahwa memang dalam Al-Qur'an terdapat struktur-struktur matematika mau pun hitungan yang sistematis dan keteraturan pola angka 19 (Iryani, 2017).

Bilangan 19 juga merupakan angka satuan terendah dan tertinggi. Diaman satu bermakna bahwa Allah satu satunya pencipta dan tuhan yang mengatur mahkluk, selain itu satu juga bermakna bahwa Allah sang pencipta adalah awal dari segala sesuatu. Sembilan merupakan anka satuan terbesar dan dapat dikaitkan dengan pahala dari ibadah seperti shalat.

Angka 19 juga memiliki makna dari 1 untuk 9 yang berarti dari Allah untuk ibadah. Ini berarti bahwa satu yaitu tuhan dan Sembilan merujuk kepada sesuatu selain tuhan yaitu ibadah yang dilakukan makhluk kepada penciptanya.

Lambang angka 19 juga akan membawa kita kepada pengembangan ilmu baru dalam matematika, ilmu pengetahuan dan juga islam. Karena diasaat ini peneliti hanya terfokus pada bilangan 1 yaitu tuhan dan pencipta dan menghubungkannya dengan unsur lain seperti 9 yang melambangkan ibadah yang akan mengambangkan kelimuan ini.

Angka 19 juga digunakan untuk penamaan pandemic baru yang sedang melanda dunia ini yaitu covid 19. Covid - 19 ini sudah melanda hampir seluruh Negara didunia yang pastinya memberikan dampak negative bagi semua orang (Hamid, 2020). Salah satu dampak yang ditimbulkan oleh pandemic ini adalah banyaknya masyarakat yang "dirumahkan" dari pekerjaan mereka, selain itu saat ini ada istilah baru yaitu work from home yaitu bekerja dari rumah yang tentu berefek pada produktifitas para pekerja. Banyak juga perusahaan yang mengalami kemerosotan keuntungan yang menyebabkan melonjaknya tingkat pengangguran karena peusahaan terpaksa melakukan PHK kepada pekerjanya karena tidak dapat membayarkan gaji mereka.

Ibadah shalat merupakan ibadah yang paling penting dari pada ibadah-ibadah yang lain. Ibadah shalat merupakan ibadah yang penting, antara lain karena tegak tidaknya Islam seseorang itu terletak pada pelaksanaan ibadah shalatnya, baik buruknya amal 
$\overline{\text { perbuatan seseorang itu terletak pada baik buruknya shalat, dengan mendirikan shalat }}$ akan selalu mendapatkan rahmat Allah SWT, serta shalat merupakan pembuka (kunci) pintu surga.

Pentingnya shalat itu pada dasarnya adalah untuk manusia itu sendiri. Oleh karena itulah maka Allah mewajibkan setiap manusia yang diciptakan-Nya untuk beribadah (shalat) kepada-Nya. Firman Allah:

"Dan aku tidak menciptakan jin dan manusia melainkan supaya mereka mengabdi kepada-Ku." (Adh-Dzariyat: 56)

Dan Firman Allah:

"Hai manusia, sembahlah Tuhanmu yang telah menciptakanmu dan orang-orang yang sebelummu, agar kamu bertakwa." (QS.2: 21).

Berdasarkan ayat-ayat Al Qur'an di atas dapatlah dipahami bahwa shalat merupakan kewajiban yang harus dilaksanakan dalam kehidupan sehari-hari sesuai ketentuan yang sudah pasti. Bagi umat Islam, shalat itu sangat penting karena Shalat merupakan penentu tegak tidaknya Islam dalam diri seseorang.

Oleh karena itu penelitian ini akan memfokuskan pembahasan pada efek negative yang ditimbulkan oleh pandemic covid 19 terutama pada bidang ekonomi yang dimana menyebabkan banyak kerugian dari perekonomian negara, perusahaan dan banyak pekerja.

\subsection{Tujuan}

Penelitian ini bertujuan untuk menjawab pertanyaan permasalahan yaitu dengan cara:

a. Menganalisis keistimewaan bilangan 19 dalam matematika serta kaitannya dengan Islam dan Hahslm.

b. Menganalisis bilangan 19 dalam penamaan Covid-19 serta dampak ekonomi yang turbulen di masa datang.

\section{Metode Penelitian}

\subsection{Metode Hahslm}

Manusia memiliki sistem kehidupan pada dirinya, di lingkungan sekitar, dan alam semesta berawal dari konsep Islam, Islam adalah konsep penciptaan awal. Kata Islam terdiri dari tiga akar kata/huruf, yaitu huruf 's' atau sin, huruf ' 1 ' atau lam, dan huruf 'm' 
atau mim. Ada ayat yang mendukung makna ontologis dari Islam yaitu QS Ali Imran (3) ayat 19, yang berbunyi:

$$
\text { الإِسنَامُ اللَّهِ عِنْدَ الدِّيّنَ إِنَّ }
$$

“Sesungguhnya Din di sisi Allah adalah Islam..” (Q.S Ali Imran [3]: ayat 19)

Definisi teori H menurut Aziz (2016) adalah:

a. Secara sempit Teori $\mathrm{H}$ diartikan sebagai teori pola dasar tiga dominan dengan konteks tertentu dalam lima dimensi susunan invarian

b. Teori $\mathrm{H}$ juga dapat diartikan sebagai teori konsep dasar pola penciptaan dengan hubungan tertentu. $\mathrm{H}$ berasal dari rumus Hahslm, AL-Quran surat Hijr, juga singkatan dari Huda atau hidup.

\subsection{Jenis Penelitian}

Jenis pemelitian deskriptif dengan menganalisis, menggambarkan, mendefinisikan, menguraikan, atau menjelaskan mengenai sistem bilangan 19 dengan Covid-19, ekonomi dan Teori H. Riset ini dilakukan dengan studi literarur mencari referensi teori yang relevan dengan Matematika 19, Covid-19 dan ekonomi.

\subsection{Ruang Lingkup Penelitian}

Ruang lingkup pada bilangan 19 dalam Matematika, Islam, dan juga Covid-19 serta ekonomi akibat pandemi.

\subsection{Metode Pengumpulan Data}

Data sekunder digunakan untuk riset ini, yang diperoleh melalui media perantara. Data ini bisa diperoleh melalui buku, catatat, bukti yang sudah ada, ataupun artikel-artikel dan jurnal-jurnal yang telah dipublikasikan untuk menjadi acuan.

\subsection{Metodologi Hahslm}

Penelitian ini menggunakan metodologi Hahslm dengan memasukkan nilai ibadah ke dalam pengolahan data. Secara kualitatif. Dalam metodologi Hahslm sudah tersimpan makna bahwa kauniyah sama dengan kauliyah.

\section{Hasil dan Pembahasan}

Di dalam teori $\mathrm{H}$ terdapat di dalamnya 19 dari angka 472319. Adapun makna yang terdapat di dalam Al Quran bawa angka 19 secara tersirat diulang beberapa kali, baik 
dalam jumlah nomer numerik lafadz basmalah, inisial surat mau pun struktur lain, namun secara tersurat sendiri. Dalam QS. Al-Hijr [15] ayat 87 Allah mengatakan bahwa telah memberikan 7 yang diulang dan Qur'an yang agung. Tafsiran "7 yang diulang" adalah angka 7. Tafsiran "Quran yang agung” menyimpan makna bilangan 2319 berupa perkalian yang berjumlah 114. Huruf-huruf digunakan sebagai lambang untuk bilangan dikenal dengan "abajadun” (Abdussakir, 2006).

Tabel 1. Nilai Numerik Huruf Hijaiyah

\begin{tabular}{cccc}
\hline Huruf & Nilai Numerik & Huruf & Nilai Numerik \\
\hline Alif & 1 & Sin & 60 \\
\hline Ba' $^{\prime}$ & 2 & Ain & 70 \\
\hline Jim & 3 & Fa' $^{\prime}$ & 80 \\
\hline Dal & 4 & Shad & 90 \\
\hline Hha & 5 & Qaf & 100 \\
\hline Wau & 6 & Ra' & 200 \\
\hline Za & 7 & Syin & 300 \\
\hline Ha' & 8 & Ta' & 400 \\
\hline Tha' & 9 & Tsa' & 500 \\
\hline Ya & 10 & Kha' & 600 \\
\hline Kaf & 20 & Dzal & 700 \\
\hline Lam & 30 & Dhad & 800 \\
\hline Mim & 40 & Dzad & 900 \\
\hline Nuun & 50 & Ghin & 1000 \\
\hline
\end{tabular}

Nilai numeric yang terkandung dalam kata Basmalah dapat juga ditentukan menjadi nilai numerik 786. Angka 30, yang merupakan bilangan komposit ke-19 dan juga merupakan jumlah juz dalam Al-Qur'an (Syah, 2014).

Ada 5 waktu shalat wajib yang dilakukan ummat Islam yaitu:
a. Shalat Shubuh 2 raka'at
b. Shalat Zhuhhur 4 raka'at
c. Shalat 'Ashar 4 raka'at 
d. Shalat Maghrib raka'at

e. Shalat 'Isya 4 raka' at

Dalam Al-quran disebutkan:

Artinya: Peliharalah semua shalat dan shalat Wustho dan laksanakanlah shalat karena Allah dengan khusyu' (QS Al-Baqoroh ; 238)

Shalat wustho menurut hadis yang sahih adalah shalat 'Ashar (tengah) nabi Muhammad SAW juga menyebut shalat wustho adalah shalat 'Ashar.

Secara akal-akalan mestinya Shalat wustho itu adalah Shalat Shubuh, karena awal hari adalah shalat Maghrib.

Maghrib, 'Isya, Shubuh, Zhuhur, 'Ashar

$\begin{array}{lllll}3 & 4 & 2 & 4 & 4\end{array}$

Tetapi mengapa nabi SAW mengatakan Shalat wustho itu = Shalat "Ashar ? jawabannya : jika hari dimulai dari Shubuh maka dapat dituliskan

$$
24434=1286 \times 19
$$

Shalat 'Ashar (tengah) karena bilangan 24434 merupakan kelipatan dari 19 dan tidak memiliki sisa maka memenuhi konsep aksioma.

Jika hari dimulai dari Maghrib dapat dituliskan

$$
34244=1802,3157895 \times 19
$$

Shalat Shubuh (tengah) karena bilangan 34244 merupakan kelipatan dari 19 dan memiliki sisa maka tidak memenuhi konsep aksioma.

Dari penjelasan di atas daoat disimpulkan bahwa yang memenuhi konsep aksioma adalah hari yang dimulai dari shalat Shubuh sehingga Shalat 'Ashar disebut shalat wustho (Shalat 'Ashar).

Adapun bilangan atau angka19 muncul pada ayat Quran dan istilah Covid-19. Dimana di dalamnya Terdapat bukti ayat kauniyah yang berupa virus dengan 19 muncul dan di dalam ayat kauliyah juga ada angka 19. Ada ayat 3.19, arti ayat 19 dan ada makna ayat yang menyimpan angka 19. Bilangan 19 ini dapat dimaknai bahwa dengan adanya virus corona ini keberadaan manusia yang mana dikembalikan ke dalam fungsinya 
asalnya yaitu untuk ibadah. Dengan Work From Home (WFH) atau bekerja dari rumah, akan merubah perilaku manusia seluruh dunia yang berakibat pada kesehatan dan krisis. Ternyata masalah ekonomi bukan hanya disebabkan oleh masalah materi atau uang saja. Ternayat ada dampak global yang hanya berawal dari mahluk mikro kecil yaitu virus corona. Dan manusia mulai menyadari bahwa ada nilai intangible yang bukan fisik yang harus juga diikutsertakan dalam setiap aktivitas di dunia yaitu adalah ibadah. Dalam Islam, manusia memang diciptakan oleh Allah dengan ide ibadah. Pada diri manusia, tersimpan simbol-simbol ibadah. Yang mana Allah telah menciptakan manusia diawali dengan model ibadah bukan model manusia itu sendiri.

Bilangan 19 pun terdapat dalam penamaan Covid-19 yang merupakan awal terjadinya penyebaran wabah virus corona ini yaitu pada akhir bulan desember 2019 . Penyebaran virus Covid-19 ini pertama kali terdapat di kota Wuhan, China. Awal penyebaran virus covid ini terdapat 266 orang yang terinfeksi di china pada akhir Desember (Mukharom, 2020).

Kasus virus ini yang mulanya diamati di provinsi Wuhan, China, sekarang sudah menyebar dengan cepat ke berbagai dunia (Nadeem, 2020). Melihat dari data atau sumber oleh beberapa pakar yang ditampilkan total kasus yang terpapar di dunia saat ini sudah mencapai 1.783.948 jiwa. Dari total tersebut terdapat 1.270.050 jiwa kasus aktif dengan 1.219.431 jiwa dengan keadaan yang tidak terlalu parah dan 50.619 jiwa dalam keadaan yang serius, serta terdapat 513.898 kasus yang 404.939 jiwa yang sembuh dan 108.959 jiwa yang meninggal (worldometers.info, 2020). Di Indonesia sendiri kasus covid-19 ini pertama kali menyebar di Indonesia pada tanggal 2 maret 2020 dimana terdapat 2 orang yang terinfeksi virus tersebut. Hingga saat ini kasus Covid- 19 ini semakin bertambah.

Saat ini masih banyak terjadi penambahan kasus covid ini dalam jumlah yang tidak sedikit. Jika dilihat dari grafik dan data diatas total kasus di Indonesia semakin meningkat dari hari ke harinya. Hal ini membuat pemerintah menerapkan kebijakan PSBB (Pembatasan Sosial Berskala Besar). Dimana dalam kebijakan ini terdapat beberapa aturan, diantaranya sistem sekolah dan kuliah menjadi online, Dimana penggunaan sistem pembelajaran online ini tidak bisa dihinari (Zaharah \& Kirilova, 2020); sistem kerja menjadi WFH atau Work From Home; pembatasan keagamaan; pembatasan kegiatan disuatu tempat; pembatasan kegiatan social; pembatasan aturan transportasi; dan yang 
lainnya. Maka dari itu sekarang tidak bisa bersosialisasi dengan orang ramai seperti sebelum adanya virus ini.

Dengan adanya pandemic covid-19 ini kondisi perekonomian Indonesia mulai menurun. Perekonomian Indonesia diperkirakan tumbuh 2,5\% pada tahun 2020. Menurut prediksi Kementerian Keuangan, ekonomi Indonesia melambat di 2020 akibat Covid-19, pulih bertahap di 2021. Yang artinya mengalami penurunan sebesar 2,5\% dari sebelmnya. Namun, jika dikutip dari CNN Indonesia, menteri keuangan republic Indonesia mengatakan bahwa proyeksi pertumbuhan ekonomi hanya akan mencapai 2,3\%. Bahkan jika kondisinya semakin memburuk, pertumbuhan ekonomi ini bisa minus $0,4 \%$. Hal ini disebabkan turunnya konsumsi.

Dengan adanya pandemik ini terdapat beberapa sektor yang paling terdampak dalam pandemic ini, diantaranya UMKM, dan pariwisata serta turunannya seperti transportasi, perhotelan, dan restoran. Dampak covid-19 bagi para pelaku UMKM ini sangat besar. Dengan adanya pandemic ini para pelaku UMKM mengalami penurunan omset yan sangat signifikan yang awalnya bisa menjual banyak produk kini hanya sedikit yang terjual. Tak banyak juga para pelaku UMKM yang mengobah metode penjualannya. Yang awalnya membuka toko disebuah ruko kini terpaksa harus tutup karena pandemic ini dan beralih memanfaatkan platform digital dalam kegiatan pemasarannya dan meringankan biaya operasional. Walaupun dengan mudah memanfaatkan platform digital dalam kegiatan pemasarannya tetapi tetap saja omset yang mereka dapatkan tidak sebanyak yang menjual di toko.

Banyak para pelaku UMKM kini mulai mengeluh karena penurunan penjualan mereka. Hal ini disebabkan karena adanya penurunan minat beli masyarakat dan terhambatnya distribusi. Tak banyak adanya pengurangan pegawai (PHK) akibat hal ini, yang dapat menyebabkan pegawai tersebut kini tidak mempunyai penghasilan sehingga mereka kesulitan untuk memenuhi sebutuhannya sehari-hari.

Sektor UMKM, sektor pariwisata dan turunannya juga terdampak. Baik itu transportasi, perhotelan, dan restoran. Dimana yang kita ketahui kini banyak tempat-temat wisata yang tutup, adanya kebijakan PSBB yang membuat aktivitas agent perjalanan sudah mendekati zero transaction atau tidak ada transaksi perjalanan sama sekali. Sehingga banyak agent-agent perjalanan yang sudah tidak beroperasi seperti sedia kala akibat terdampak virus Covid-19.

Agen perjalanan dalam negeri pun ikut terdampak oleh penyebaran virus Covid19 karena minat masyarakat semakin menurun apalagi sekarang diterapkan kebijakan 
tidak boleh mudik. Membuat agen perjalanan semakin beku. Banyak agen perjalanan sejak awal maret tidak lagi beroperasional membuat perusahaan agent perjalanan tersebut tidak mendapatkan pemasukan lagi. Jika seperti ini bisa membuat karyawan agen perjalanan tersebut di PHK karena melemahnya perusahaan agen tersebut.

UMKM sangat perlu melakukan analisis prediksi masa depan, untuk menganalisis perubahan Produk Domestik Bruto (PDB) untuk di masa yang akan datang. Matematika dapat dimanfaatkan untuk membuat rumus preduksi penurunan ekonomi akbat PSBB atau Moderate Lockdown yang diterapkan oleh pemerintah. Setelah masyarakat menjalankan social distancing secara ketat, maka penularan Covid-19 mulai berkurang. Matematika bisa membuat prediksi ekonomi dengan rumus Moderate Lockdown (ML): 0,95X2$3,9 \mathrm{X}+5$.

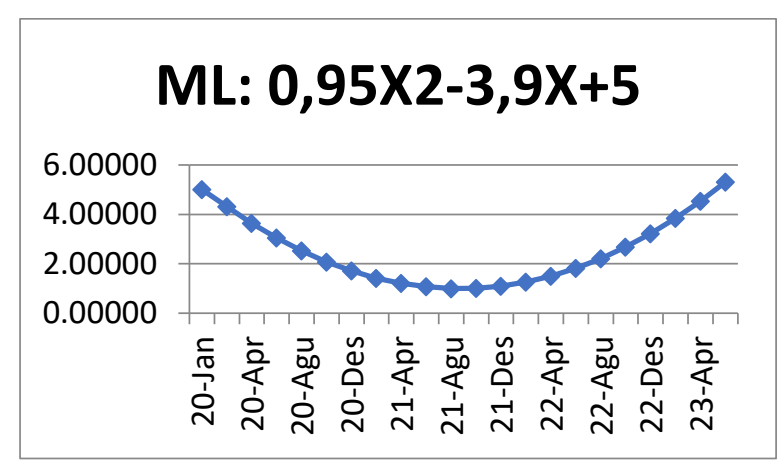

Gambar 1. Grafik PDB Dengan Moderate Lockdown (ML)

Sumber: Analisis, 2020

Dengan diberlakukannya Moderate Lockdown seperti di Indonesia akan mengalami perubahan GDP. Hasil analisis di atas merupakan data perubahan PDB dari Januari 2020 hingga bulan Juni 2023.

Sejak diberlakukannya Moderate Lockdown pendapatan suatu Negara sedikit demi sedikit mengalami penurunan. Pada Januari 2020 pendapatan suatu Negara menunjukan angka sebesar 5,00005 dan mengalami penurunan sampai bulan Agustus 2021. Dimana bulan Agustrus 2021 itu merupakan titik terendah pendapatan suatu Negara yang menunjukan pendapatan suatu Negara hanya sebesar 1,00005 yaitu pada bulan Agustus. Dan mulai mengalami kenaikan kembali dari bulan Oktober 2021 hingga juni 2023. Indonesia pada bulan Mei-Juni 2020 menunjukan penurunan PDB akibat 
diberlakukannya Moderate Lockdown. Dan PDB akan kembali pulih ke arah yang lebih sejalan dengan proses penyehatan akibat Covid-19 dan harapan ditemukannya obat serta vaksin anti virus di tahun depan.

\section{Kesimpulan}

Konsep matematika dalam Al-quran secara garis besar meliputi kajian tentang; aljabar (bilangan dan operasinya), himpunan, geometri dan pengukuran, logika, statistika dan estimasi Di dalam islam juga terdapat banyak Bilangan 19 matematika. Banyak bilangan 19 dalam Islam yang dapat diketahui sebagi makna Tuhan dan perintah ibadah yang tersimpan dalam Teori H. Matematika 19 dan Covid-19 serta Teori H yang menyimpan makna 19 merupakan simbol kebesaran Allah. Dan ibadah adalah tujuan diciptakannya alam semesta ini. Allah mengawali penciptaan dari makna ibadah bukan dengan model manusia.

Bilangan 19 juga memiliki kesamaan dengan penamaan Covid-19 yang menjadikan pandemi secara global. Dengan adanya pandemi Covid-19 ini membuat pertumbukan ekonomi Indonesia menjadi turun dari tahun sebelumnya. PDB turun, ekonomi seluruh dunia terkontraksi, dan akan pulih seiring dengan kedisiplinan untuk Social Distancing dan harapan vaksin di tahun depan.

\section{Pustaka}

Abdussakir. 2017. Ada Matematika Dalam Al-Quran. Jurnal EduTech Vol. 3 No. 1 Maret 2017. 3(1), 1-11. https://doi.org/jmn0228-3 [pii]

Awan, N. M. 2009. Quran and Mathematics-I. In Jihāt al-Islām (Vol. 3, Issue JulyDecember, $\quad$ pp. 39-59). http://iri.aiou.edu.pk/indexing/wpcontent/uploads/2016/07/11-quran-and-mathematics.pdf

Aziz, R. M. 2019. “God Equation Of Hahslm 472319 In Universe Creation”. Senatik, Vol $1, \operatorname{Pg} 452-461$.

Aziz, RM. 2016. “Islam dan Pengetahuan”. Salemba Diniyah, Jakarta.

Aziz, Roikhan Mochamad. 2016. Teori H dalam Islam Sebagai Wahyu dan Turats. Jurnal Ushuluddin, UIN Riau. Volume 24 Nomor 1. ISSN: 1412-0909/E-ISSN: 24078247. http://ejournal.uin-suska.ac.id/index.php/ushuludin

Basya, Fahmi. 2004. "Matematika Islam (Matematika Al-quran)”, Jakarta: Pusat Studi.

Basya, Fahmi. 2003. "Matematika Al-Quran”. Jakarta: Pustaka Quantum Prima.

Basya, Fahmi. 2005. “Matematika Islam”. Jakarta: Penerbit Republika. 
Hamid, A. R. A. H. 2020. Social responsibility of medical journal: A concern for covid19 pandemic. Medical Journal of Indonesia, 29(1), 1-3. https://doi.org/10.13181/mji.ed.204629

Huda, M., \& Mutia, M. 2017. Mengenal Matematika dalam Perspektif Islam. Fokus Jurnal Kajian Keislaman Dan Kemasyarakatan, 2(2), 182. https://doi.org/10.29240/jf.v2i2.310

Irawan, W. H., Abdussakir, \& Kusumawati, A. 2005. Rahasia bilangan dalam Al- Qur ' an. Penelitian Ilmu Pengetahuan Terapan, 01, 66.

Iryani, E. 2017. Al- Qur'an Dan Ilmu Pengetahuan. Jurnal Ilmiah Universitas Batanghari Jambi, 17(3), 66-83.

Johanes., Kastolan. 2003. “Kompetensi Matematika”. Jakarta: Nudhistira

Mukharom, M., \& Aravik, H. 2020. Kebijakan Nabi Muhammad Saw Menangani Wabah Penyakit Menular dan Implementasinya dalam Konteks Penanggulangan Coronavirus Covid-19. Salam: Jurnal Sosial Dan Budaya Syar-I, 7(3). https://doi.org/10.15408/sjsbs.v7i3.15096

Nadeem, S. 2020. Coronavirus Covid-19: Available Free Literature Provided By Various Companies, Journals and Organizations Around the World. J Ong Chem Res, 5 (1) (March), 7-13. https://doi.org/10.5281/zenodo.3722904

Nasution, A. A. 2013. Matematika dalam Al-Quran. Logaritma, 1(1), 112-122. https://doi.org/http://dx.doi.org/10.1111/j.1532-5415.2008.01851.x

Nasution, Abdul Fattah. 2017. Impelemntasi Konsep Matematika Dalam Al-Quran Kurikulum Madrasah. Labuhanbatu. Al Washliyah University Labuhanbatu, Indonesia https://media.neliti.com/media/publications/59024-ID-implementasikonsep-matematika-dalam-al.pdf

Nishiura, H., Linton, N. M., \& Akhmetzhanov, A. R. 2020. Serial interval of novel coronavirus (COVID-19) infections. International Journal of Infectious Diseases, 93, 284-286. https://doi.org/10.1016/j.ijid.2020.02.060

Syah Aji, R. H. 2014. Khazanah Sains Dan Matematika Dalam Islam. Salam: Jurnal Sosial Dan Budaya Syar-I, 1(1). https://doi.org/10.15408/sjsbs.v1i1.1534

Whiteside, D. T. 1978. Islamic Mathematics. Nature, 273(5657), 78-78. https://doi.org/10.1038/273078a0

WHO. 2020. Coronavirus Disease 2019 (COVID-19) Situation Reports. April 12020. WHO Situation Report, 2019(72), 1-19. https://www.who.int/docs/defaultsource/coronaviruse/situation-reports/20200324-sitrep-64-covid19.pdf?sfvrsn=703b2c40_2\%0Ahttps://www.who.int/docs/defaultsource/coronaviruse/situation-reports/20200401-sitrep-72-covid19.pdf?sfvrsn=3dd8971b_2 
Zaharah, Z., \& Kirilova, G. I. 2020. Impact of Corona Virus Outbreak Towards Teaching and Learning Activities in Indonesia. Salam: Jurnal Sosial Dan Budaya Syar-I, 7(3). https://doi.org/10.15408/sjsbs.v7i3.15104 